$\square$ 報告 $24 \square$

\title{
Commodity Tax Harmonisation and Global Tariff Reduction with International Oligopoly
}

\author{
Toyama University Naoki Kakita \\ Toyama University Kazuyuki Nakamura \\ Aichi University Minoru Kunizaki
}

JEL classification number : F12, F13, F15, H20

Keywords : international oligopoly; tax harmonisation; tariff reduction

The purpose of this paper is to examine the welfare effects of the reforms from unilateral domestic policy to global tariff reduction and commodity tax harmonisation under imperfect competition.

Much literature analyses the effect of international commodity tax and tariff reforms on the world welfare. For example, Hatta and Fukushima (1979) has shown that a proportional tariff reduction is potentially Pareto-improving. Accordingly, Turunen-Red and Woodland (1992) has argued that strictly Pareto-improvement may be achieved under the several conditions.

Concerning commodity tax reform, on the other hand, Keen (1987) has presented that it is potentially Pareto-improving. Keen (1989a) has argued that commodity tax reform can be strictly Pareto-improving.

All works mentioned above, however, have assumed to be perfect competition. There are few works concerning problems under imperfect competition except for Keen and Lahiri (1993). They argued that, using imperfect competition model, the commodity tax harmonisation is potentially Pareto-improving and is also strictly Paret-improving starting from a non-cooperative Nash equilibrium. They consider a single commodity market with commodity taxes and production subsidies. The results of reforms are still ambiguous in the multiproduct oligopoly. The above reform may be more highly recommended if the similar results of previous works are assured under the multiproduct oligopoly.

In this paper, we then examine the welfare effects of a commodity tax harmonisation and a global tariff reduction using a two-country intra-industry trade model. For this purpose, we sup-

E-mail：kakita@ecu.toyama-u.ac.jp 
pose the following throughout the paper: (i) linear demand curves; (ii) constant marginal costs; (iii) Cournot conjectures; (iv) two differentiated products. All these are usual assumptions for the analysis under oligopolistic market. However, assumption (iv) allows us to analyse tariff reform in integrated world market.

We consider a two (domestic and foreign) country intra-industry trade model. Each country produces two final tradable goods by a single factor of production which is in fixed supply. One of two goods is produced for a competitive market and chosen as a numeraire.

The other goods compete in the international oligopolistic market and are nationally differentiated. We suppose that both countries are importing each other's products in order to consume both products. It is also impossible for the firms to independently vary the prices in each country, when the markets are integrated. The domestic country consumes the domestic and foreign products, $x$ and $y$, at the consumer price, $p_{x}$ and $p_{y}$ respectively. The foreign country is also the same as the domestic country, where foreign variables are denoted by asterisk. Then the total outputs of domestic and foreign frms are $X=x+x^{*}$ and $Y=y+y^{*}$.

The domestic government imposes commodity tax $e$ on domestic consumption and tariff $t$ on imports, corresponding policy instruments for the foreign government are $e^{*}$ and $t^{*}$. Throughout this paper, the international treatment of the commodity taxes follows the destination principle. In this paper, we only focus on the case of the specific tariff and tax rates.

We mainly show that:

(1) Unilateral commodity tax reduction and tariff reduction under the plausible conditions are always strictly potentially Pareto-improving.

(2) From starting any positive tariff rates, strictly Pareto-improving can be achieved by global tariff reduction.

(3) Commodity tax harmonisation can be strictly Pareto-improving.

* We especially thank Professor Noritsugu Nakanishi for his helpful comments and discussion on our paper. We also thank Professor Kenzo Abe for his helpful suggestions.

\section{References}

Hatta, Tatsuo and T. Fukushima, 1979, “The welfare effect of tariff rate reductions in a many country world", Journal of International Economics 9, 503-511. 
Kakita, Naoki, K. Nakamura and M. Kunizaki, 1998, “Commodity tax harmonisation and global tariff reduction with international oligopoly”, Toyama University Working Paper 175.

Keen, Michael J., 1987, "Welfare effects of commodity tax harmonisation", Journal of Public Economics 33, 107-114.

Keen, Michael J., 1989, "Pareto-improving indirect tax harmonisation", European Economic Review 33, 1-12.

Keen, Michael J. and Sajal Lahiri, 1993, "Domestic tax reform and international oligopoly", Journal of Public Economics 51, 5-74.

Turunen-Red, Arja and A. Woodland, 1992, "Multilateral reforms of tariffs without transfer compensation", in H. Herberg and N. van Long (eds.), Trade, Welfare and Economic Policies: Essays in Honor of Murray Kemp (Ann Arbor: University of Michigan Press), 145166 